\title{
How Air-Drying Affects DGT P Results in Calcareous Soils
}

\author{
Yulin Zhang, Yanli Wang, Yaru Tan, Limin Li, Xudong Wang* \\ College of Resources and Environment, Northwest A and F University, Yangling, P.R. China
}

Received: 16 December 2017

Accepted: 4 March 2018

\begin{abstract}
Diffusive gradients in thin films (DGT) technology has been increasingly proved to be a promising tool for accurately predicting plant-available phosphorus (P) in soil using air-dried samples. However, the effects of the air-drying process on DGT-measured $\mathrm{P}$ are unknown compared to those of using moist samples in which plant roots survive throughout a growing season. We investigated the differences between the Olsen P and DGT P values in 58 air-dried and moist soil samples. The results showed that the discrepancy in the DGT P values between air-dried and moist samples increased with an increase in the organic $\mathrm{P}$ concentration in soils. It was presumed that the air-drying process converted some easily mineralized organic P into its inorganic form, thereby allowing it to be measured by the DGT method. The DGT P values in moist samples can be calculated from the values obtained in air-dried samples using the following equation: . However, the Olsen $\mathrm{P}$ values were highly correlated $\left(\mathrm{R}^{2}=0.95\right)$ when using air-dried and moist samples, although significant differences were observed. We concluded that the effects of air-drying on predicting soil available P using the Olsen P method can be neglected due to the high correlation relationship. The availability of easily mineralized organic $\mathrm{P}$ needs to be further explored.
\end{abstract}

Keywords: DGT, phosphorus, air-drying, soil testing

\section{Introduction}

As a limited macronutrient, phosphorus $(\mathrm{P})$ is widely used in agriculture to maintain a high crop yield. Due to poor fertilizer management and the variations in soil properties, overfertilization is common around the world. Excess $\mathrm{P}$ in the environment can cause water eutrophication, threaten human health, and endanger the ecosystem $[1,2]$. At the same time, other areas suffer from severe yield limitations due to low $\mathrm{P}$ availability in soils $[3,4]$. Great efforts have been made to improve

*e-mail: wangxudong01@126.com the accuracy of soil testing methods for predicting the plant $\mathrm{P}$ requirements before seeding, aiming to reduce the extra $\mathrm{P}$ input while optimizing the crop yield. A water/chemical extraction procedure is usually the main process in the traditional method for measuring the soil available P; i.e., an air-dried soil sample is mixed with chemicals at a certain ratio, and the mixture is shaken for a period of time to allow an equilibrium of $\mathrm{P}$ between the solution and soil solid phase to be reached. The amount of $\mathrm{P}$ extracted in the solution is used to express the available $\mathrm{P}$ amount in soils. However, even for the most acceptable extraction method, Olsen P, the fertilization recommendations can vary by up to 3 times the amount for soils with the same Olsen P status [5]. 
Compared to the traditional extracting methods, the diffusive gradients in thin films (DGT) technique is a promising tool for testing the available elements in a solution. The method has been mostly used to assay metal elements in water, such as $\mathrm{Cd}, \mathrm{Cu}, \mathrm{Fe}, \mathrm{Mn}, \mathrm{Ni}$, and $\mathrm{Zn}$ [6-9], and it has been successfully used to assay $\mathrm{Cd}$ and $\mathrm{Zn}$ in sediments [10] and $\mathrm{N}$ and $\mathrm{K}$ in soils [11-15]. Greater accuracy was found for predicting plant-available $\mathrm{P}$, for which the dominant uptake mechanism by plant roots is diffusion, using the DGT method compared to the traditional extraction methods [16-20]. This accuracy has also been proved by recent findings. For example, it was reported that the DGT $\mathrm{P}$ result was highly correlated to the maize $\mathrm{P}$ uptake in a pot experiment corresponding to an application of sewage sludge-based $\mathrm{P}$ fertilizer [21], and to that of wheat [22]. DGT also showed great accuracy in predicting the barley leaf $\mathrm{P}$ concentrations in both pot and field experiments [23].

The DGT device consists of two parts. The first part is a plastic piston and a plastic cap with a window of area A. The function of this part is to hold together the gel assembly. The gel assembly contains two polyacrylamide gels (the diffusive gel and the binding layer) and an additional membrane filter that acts as a protective barrier for the gels. The theory behind using DGT to assess the available elements in soil environments has previously been described by Zhang et al. [10], Mason et al. [24], and Degryse et al. [25]. Simply put, when a DGT device is deployed in water-saturated soil samples, the target element in the soil solution diffuses through the diffusive gel and accumulates in the resin gel. When the element's concentration at the DGT surface is lowered by the resin gel uptake, the element from the soil solid phase desorbs to replenish this depletion. Therefore, the fraction of an element measured by the DGT is assumed to incorporate the soluble pool and part of the insoluble pool from the soil solid phase and is identical to the pools of $\mathrm{P}$ uptake by plants.

The routine processes of preparing a soil sample for a DGT test include air-drying and sieving ( $\leq 2 \mathrm{~mm})$ to maintain the homogeneity and representativeness of soil samples. However, it is widely accepted that the air-drying process may cause changes in soil $\mathrm{P}$ fraction and its availability to plants. It is reported that the drying and wetting cycle significantly increases the soil dissolved inorganic P in beech and spruce forest soils [26], glasshouse soils [27], and crop fields [28]. As the DGT P results are assumed to be more closely related to plant $\mathrm{P}$ uptake compared to the results of traditional extraction methods, the effects of the drying process on measured DGT P concentration in different soil types are not clear yet.

The effects of air-drying on available $\mathrm{P}$ extracted by traditional methods have been extensively reported, but there is a lack of information on the DGT P results. To accurately predict the plant-available $\mathrm{P}$ using the DGT method, it is important to understand how the airdrying process affects the diffusion process of element uptake by the DGT device and the DGT P concentration in soils. The aims of this study are: 1) to investigate the relationship of DGT $P$ values in air-dried and moist samples and 2) to reveal the factors affecting the DGT P values in air-dried and moist samples.

\section{Material and Methods}

\section{Study Area and Sampling Sites}

The study area is in the Loess Plateau $\left(34-40^{\circ} \mathrm{N}\right.$, $101-114^{\circ} \mathrm{E}$ ) in China (Fig. 1), which belongs to a warm, or temperate, continental monsoon climate. The annual precipitation ranges from $200 \mathrm{~mm}$ in the northwest to $750 \mathrm{~mm}$ in the southeast, and the rainy season (June-September) accounts for $60-70 \%$ of the total annual precipitation. The Loess Plateau is typified by its fragile ecosystem. Therefore, it is important to precisely manage the $\mathrm{P}$ nutrient levels in this area using an accurate soil-testing method. Soil samples $(0-20 \mathrm{~cm})$ were collected from the Loess Plateau areas. The moist samples were stored at $4^{\circ} \mathrm{C}$ in a refrigerator before soil testing.

\section{Soil Testing}

\section{Basic Soil Properties}

Soil $\mathrm{pH}$ was measured using a soil-to-solution ratio of 1:2.5 by a $\mathrm{pH}$ meter (PHS-3C, Shanghai) [29]; EC was measured at a soil-to-water ratio of 1:5 (DDS-307A, Shanghai) [30]; CEC was measured in an extraction solution of $1 \mathrm{~mol} \mathrm{~L}^{-1} \mathrm{NaOAc}$ [30]; SOM were measured using a dichromate oxidation method [31]; and the $\mathrm{CaCO}_{3}$ content was estimated as weight reduction of the soil sample after acid washing procedures: $10 \mathrm{~g}$ of the soil sample was washed with $0.05 \mathrm{~mol} \mathrm{~L}^{-1} \mathrm{HCl}$ continuously until there was no carbonate reaction. Particle size was measured using the method described

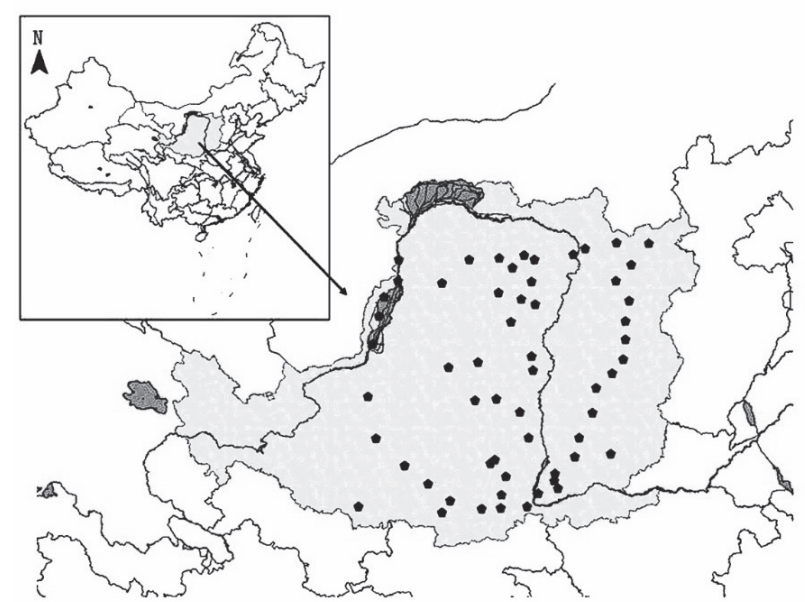

Fig. 1. Sampling sites. 
Table 1. Basic soil properties categorized by soil texture; "n" refers to the number of soil samples, "SD" means standard deviation, "NA" means not available.

\begin{tabular}{|c|c|c|c|c|c|c|c|c|c|c|c|c|}
\hline \multirow{2}{*}{ Soil texture } & \multicolumn{2}{|c|}{$\mathrm{pH}$} & \multicolumn{2}{c|}{$\mathrm{EC}\left(\mu \mathrm{cm}^{-1}\right)$} & \multicolumn{2}{c|}{$\mathrm{CEC}\left(\mathrm{cmol} \mathrm{kg}^{-1}\right)$} & \multicolumn{2}{c|}{$\mathrm{SOM}\left(\mathrm{g} \mathrm{kg}^{-1}\right)$} & \multicolumn{2}{c|}{$\mathrm{CaCO}_{3}(\%)$} & \multicolumn{2}{c|}{$\mathrm{Clay}(\%)$} \\
\cline { 2 - 15 } & Mean & SD & Mean & SD & Mean & SD & Mean & SD & Mean & SD & Mean & SD \\
\hline Sand $(\mathrm{n}=3)$ & 8.23 & 0.14 & 60 & 13 & 1.43 & 0.09 & 3.28 & 1.47 & 1.39 & 0.04 & 1.97 & 0.62 \\
\hline Loamy sand $(\mathrm{n}=7)$ & 8.16 & 0.08 & 135 & 82 & 2.67 & 0.99 & 10.80 & 6.23 & 2.35 & 0.23 & 5.38 & 1.81 \\
\hline Sandy loam $(\mathrm{n}=5)$ & 8.00 & 0.16 & 192 & 97 & 4.35 & 0.57 & 15.00 & 4.46 & 1.56 & 0.60 & 5.44 & 2.80 \\
\hline Silt $(\mathrm{n}=1)$ & 7.91 & NA & 374 & NA & 3.64 & NA & 21.44 & NA & 1.96 & NA & 3.20 & NA \\
\hline Silt loam $(\mathrm{n}=33)$ & 8.03 & 0.25 & 277 & 212 & 3.10 & 1.04 & 16.85 & 8.69 & 1.49 & 0.69 & 13.98 & 6.26 \\
\hline Loam $(\mathrm{n}=3)$ & 7.99 & 0.12 & 234 & 50 & 2.11 & 0.27 & 10.72 & 0.89 & 1.78 & 0.25 & 18.30 & 6.76 \\
\hline Silty clay loam $(\mathrm{n}=5)$ & 8.07 & 0.09 & 290 & 97 & 3.35 & 0.91 & 12.49 & 3.06 & 1.03 & 0.30 & 32.46 & 3.92 \\
\hline Clay loam $(\mathrm{n}=1)$ & 8.02 & NA & 197 & NA & 2.84 & NA & 9.57 & NA & 2.12 & NA & 32.04 & NA \\
\hline
\end{tabular}

by J. Benton Jones [32]. The basic properties are summarized in Table 1.

\section{Soil P Measurement}

Solution $\mathrm{P}$ was extracted at a soil-to-water ratio of 1:5 for $30 \mathrm{~min}$ [33]. Olsen $\mathrm{P}$ was extracted at a soilto-solution $\left(\mathrm{NaHCO}_{3}\right.$ solution, $\mathrm{pH}$ 8.5) ratio of $1: 20$ for $30 \mathrm{~min}$ [34]. Inorganic $\mathrm{P}$ contained $\mathrm{Ca}_{2}-\mathrm{P}, \mathrm{Ca}_{8}-\mathrm{P}$, $\mathrm{Ca}_{10}-\mathrm{P}, \mathrm{Fe}-\mathrm{P}$, Al-P, and O-P, and the extracting methods were described by Jiang and Gu [35]. Total P (TP) was extracted using an $\mathrm{HClO}_{4}$ solution at approximately $350^{\circ} \mathrm{C}$ [33], and organic $\mathrm{P}$ was estimated as the difference between TP and inorganic P. DGT P was extracted according to previously published procedures [36] using diffusive gels with a thickness of $0.78 \mathrm{~mm}$. For those moist soil samples, water was added until the point of saturation (assessed visually) overnight to allow the soil aggregates to disperse. Plant root debris and other substances were carefully separated and discarded using tweezers and a small rake before DGT deployment. Phosphorus concentration in the extraction solution, obtained using the solution P-method, was measured using a UV-VIS spectrophotometer (UV-2450, Japan) at $\lambda=620 \mathrm{~nm}$.

\section{Difference in Olsen and DGT P Values on Air-Dried and Moist Soil Samples}

Olsen and DGT P were measured in air-dried and moist soil samples, respectively. The discrepancy between soil available $\mathrm{P}$ values before and after the air-drying process reflects the degree to which the airdrying process affected the results using a specific soil testing method. $\triangle$ Olsen $\mathrm{P}$ and $\triangle \mathrm{DGT} \mathrm{P}$ were calculated using equations 1 and 2 as follows:

$$
\begin{gathered}
\Delta \text { Olsen } \mathrm{P}=\text { Olsen } P_{d r y}-\text { Olsen } P_{\text {moist }} \\
\Delta \text { DGT } \mathrm{P}=D G T P_{d r y}-D G T P_{\text {moist }}
\end{gathered}
$$

Relative discrepancy of DGT was termed to be:

$$
\begin{gathered}
\text { Relative discrepancy }= \\
\Delta \text { DGT P } /\left(\text { DGT } \mathrm{P}_{\text {dry }}+\text { DGT } \mathrm{P}_{\text {moist }}\right) / 2
\end{gathered}
$$

According to the relative discrepancy of DGT P, the soils were divided into 3 groups: Group $1(\leq-20 \%)$; Group $2(-20 \%-20 \%)$; and Group $3(\geq 20 \%)$. The main factors were identified according to the significantly different factors among the 3 groups.

\section{Statistical Analysis}

Correlations between the values obtained from the different soil $\mathrm{P}$ test methods and soil properties were assessed using the Spearman correlation method in the SigmaPlot 12.0 software. A paired sample $T$ test was carried out to test the significance between soil $\mathrm{P}$ values obtained before and after the air-drying process using the Olsen and DGT P methods using IBM SPASS Statistics 20. Analysis of variance (ANOVA) was performed using IBM SPASS Statistics 20 to assess whether the selected soil parameters were significantly different between different groups of soils varying in discrepancies in DGT P values in air-dried and moist samples.

\section{Results and Discussion}

\section{Relationships of Olsen P and DGT P on Air-Dried and Moist Samples}

Significant differences in soil-available $\mathrm{P}$ values using Olsen P and DGT P methods were found between samples obtained before and after the air-drying process $(\mathrm{P}<0.01)$, irrespective of excluding the outliers (open symbols in Fig. 2) or not. Compared to the results from the Olsen P method, the correlation relationship obtained using the DGT P method was poorer, suggesting that 

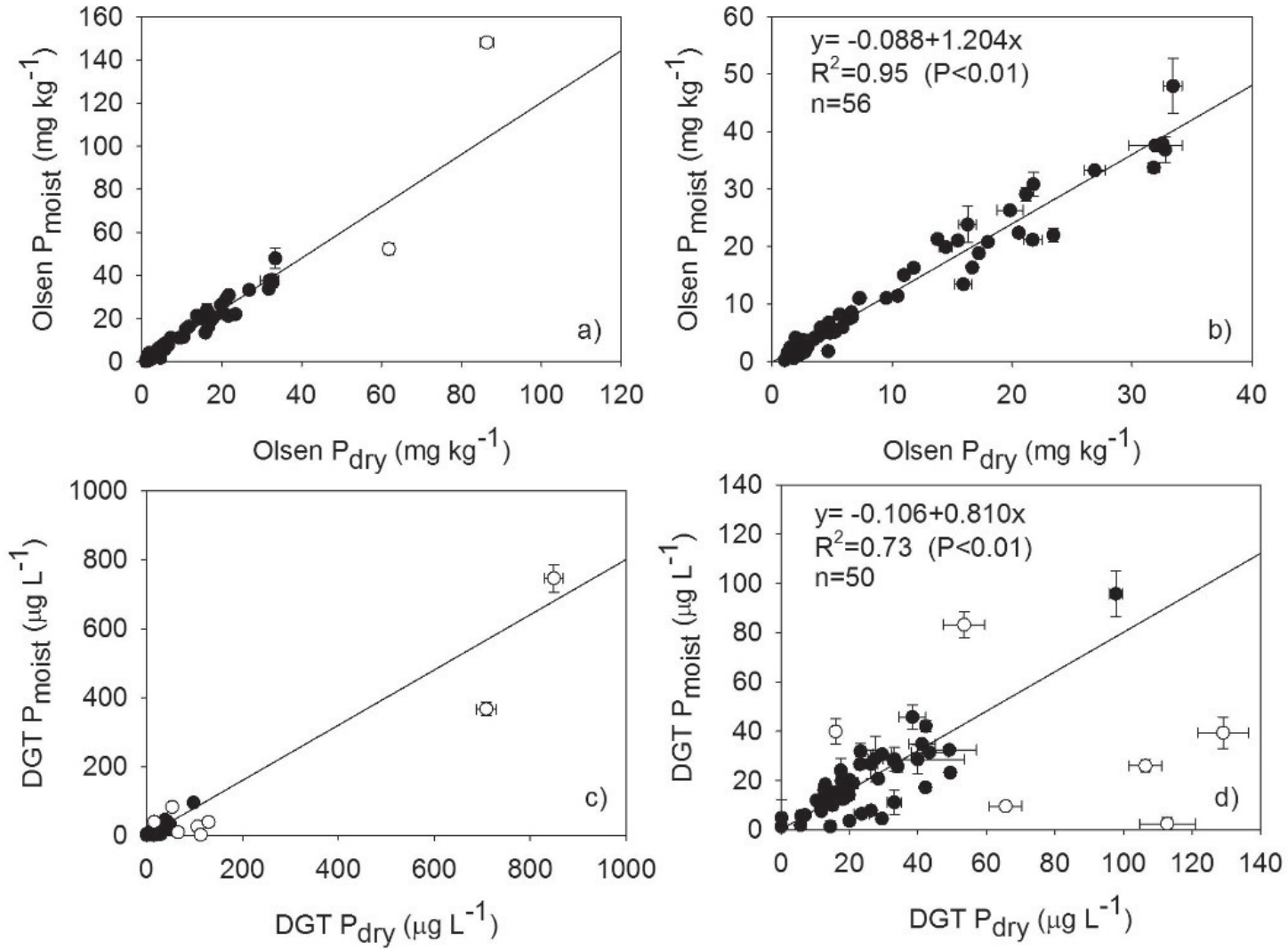

Fig. 2. Relationships between soil $P$ values on air-dried and moist samples using Olsen $P(a$ and $b)$ and DGT P (c and d) methods; the equations were obtained using soil samples, excluding the outliers.

the air-drying process has more impact on the DGT $P$ results than the traditional Olsen $\mathrm{P}$ results.

There was a strong positive correlation relationship between Olsen $\mathrm{P}$ values using air-dried and moist samples $\left(\mathrm{R}^{2}=0.95\right)$ while excluding 2 outliers. Therefore, Olsen $\mathrm{P}_{\text {moist }}$ can be calculated using equation (4):

$$
\text { Olsen } \mathrm{P}_{\text {moist }}=-0.088+1.204 \times \text { Olsen } P_{d r y}
$$

The slope was larger than 1, illustrating that the air-drying process decreased extractable $\mathrm{P}$ from soils using the Olsen P method. Obalum and Chibuike [37] reported that the process of soil air-drying increased and decreased the available $\mathrm{P}$ in upland and lowland soils respectively, and attributed the reason to the release of mobilized P by Fe (III) oxyhydroxides via the redox reaction in soils [38, 39]. Soinne et al. [40] reported that drying changed $\mathrm{P}$ distribution in soil particles with different sizes. In our study, the air-drying process did not affect Olsen $\mathrm{P}$ results to a large extent. However, due to the high correlation between the Olsen $\mathrm{P}$ values in air-dried and moist soil samples, we assumed that the effects of the air-drying process on Olsen $\mathrm{P}$ could be neglected.

Table 2. Pearson correlation between soil properties and measured ratios of $\mathrm{P}$ to inorganic or TP using different soil $\mathrm{P}$ extraction methods; “*” means significant correlation at $\mathrm{P} \leq 0.05$ level and "*** means significant correlation at $\mathrm{P} \leq 0.01$ level.

\begin{tabular}{|c|c|c|c|c|c|c|c|}
\hline Soil property & $\begin{array}{c}\text { Soluble P } \\
\text { /inorganic P }\end{array}$ & $\begin{array}{c}\text { Olsen } \mathrm{P}_{\text {dry }} \\
\text { /inorganic } \mathrm{P}\end{array}$ & $\begin{array}{c}\text { DGT } \mathrm{P}_{\text {dry }} \\
\text { /inorganic } \mathrm{P}\end{array}$ & Soluble P/TP & Olsen $\mathrm{P}_{\mathrm{dry}} / \mathrm{TP}$ & ${\text { DGT } \mathrm{P}_{\text {dry }} / \mathrm{TP}}_{\text {Inorganic P/TP }}$ \\
\hline $\mathrm{pH}$ & 0.192 & -0.132 & 0.119 & 0.196 & -0.191 & 0.115 & -0.122 \\
\hline $\mathrm{EC}$ & -0.162 & 0.214 & 0.011 & -0.163 & 0.253 & 0.032 & 0.23 \\
\hline $\mathrm{CEC}$ & $-0.307^{*}$ & 0.049 & -0.059 & $-0.282^{*}$ & 0.035 & -0.058 & $-0.280^{*}$ \\
\hline $\mathrm{SOM}$ & -0.023 & $0.288^{*}$ & $0.276^{*}$ & 0.018 & $0.302^{*}$ & $0.292^{*}$ & 0.071 \\
\hline $\mathrm{CaCO}_{3}$ & -0.045 & 0.116 & 0.067 & -0.066 & 0.09 & 0.054 & $-0.376^{* *}$ \\
\hline $\mathrm{Clay}$ & -0.102 & $0.460^{* *}$ & -0.118 & -0.087 & $0.474^{* *}$ & -0.09 & 0.196 \\
\hline
\end{tabular}




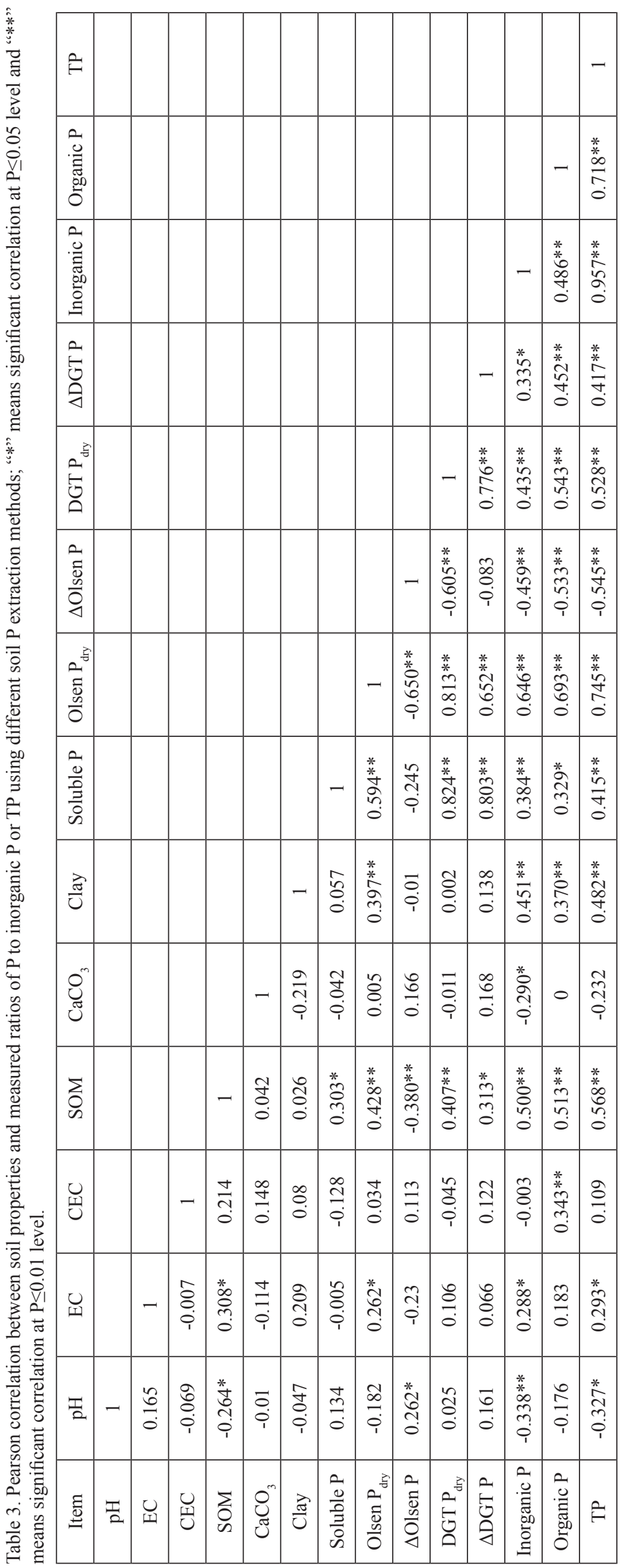


Compared to the Olsen $\mathrm{P}$ method, the correlational relationship between DGT $\mathrm{P}$ values using air-dried and moist samples was poorer $\left(\mathrm{R}^{2}=0.73\right)$ while excluding 8 outliers (open symbols). DGT $\mathrm{P}_{\text {moist }}$ was calculated using equation (5):

$$
\text { DGT } P_{\text {moist }}=-0.106+0.810 \times D G T P_{d r y}
$$

The slope was smaller than 1, illustrating that the air-drying process increased DGT-extractable $\mathrm{P}$ amount from soils. A lower correlational relationship between
DGT P values using air-dried and moist samples and obtaining more outliers using the DGT method than the Olsen $\mathrm{P}$ method indicated that the air-drying process had greater effects on the DGT P results than the Olsen $P$ results in relation to other soil properties.

\section{Soil Properties and Soil P Measured Using Different Methods}

We analyzed the relationships between the soil properties and ratios of soil $\mathrm{P}$ to inorganic $\mathrm{P}$ and TP.
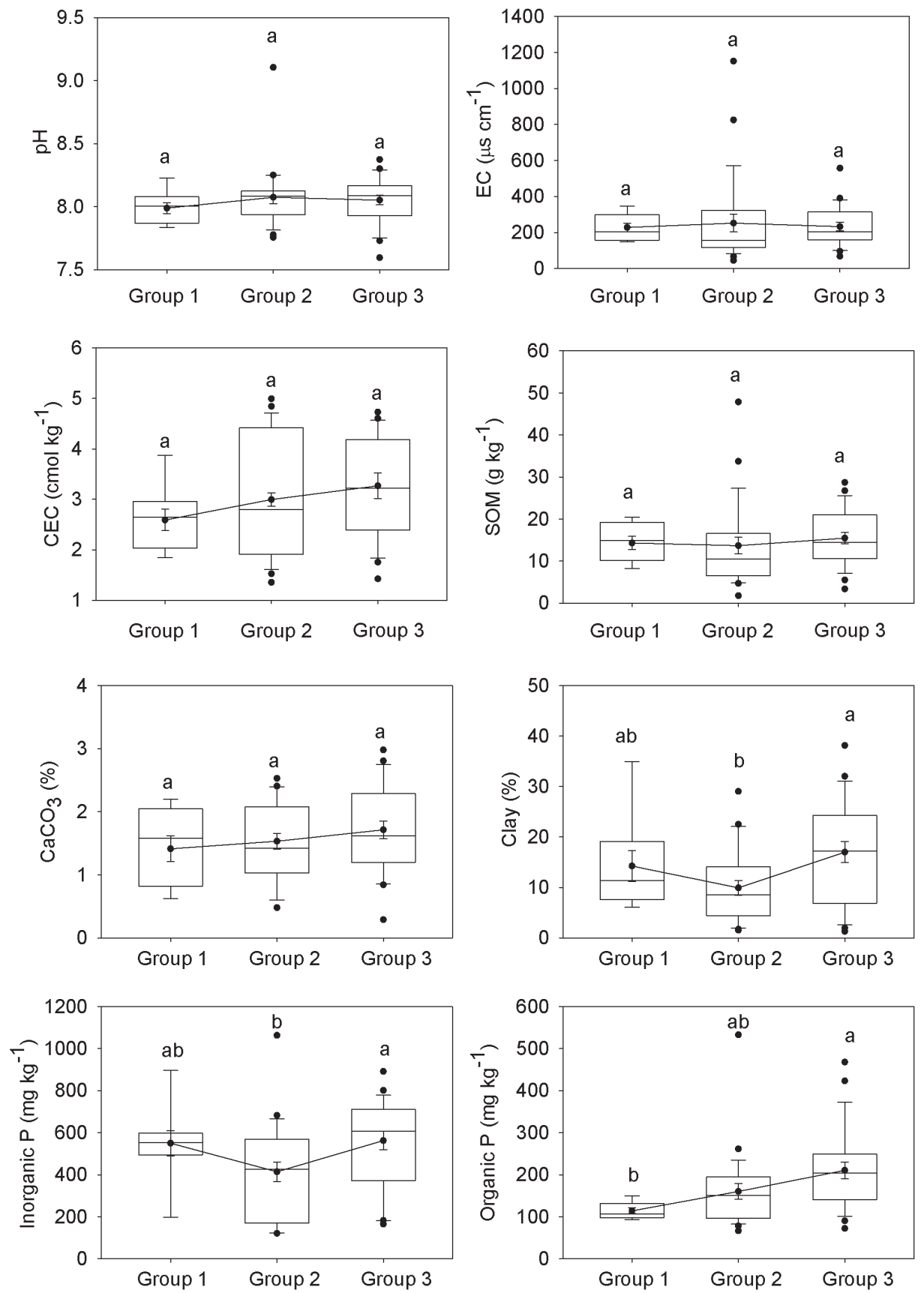

Fig. 3. Soil property parameters in different groups of soils varied with the relative discrepancy of DGT P values; Group 1 represents soils with a relative discrepancy $\leq-20 \%$; Group 2 represents soils with a relative discrepancy between $-20 \%$ and $20 \%$; and Group 3 represents soils with a relative discrepancy $\geq 20 \%$; different letters mean significant differences at the $\mathrm{P} \leq 0.05$ level. 
The results showed that soil $\mathrm{pH}$ had no correlation with any proportion of $\mathrm{P}$ pools in soils (Table 2). The reason was probably that the soil $\mathrm{pH}$ in the Loess Plateau did not vary greatly. Similarly, it was reported that soil $\mathrm{pH}$ and $\mathrm{CaCO}_{3}$ had little or no effect on the dynamics of phosphate ions in acidic and none-acidic soils [41]. High correlations were observed between the ratios of Olsen P/inorganic P and Olsen P/TP with SOM and clay content in soils $(\mathrm{P} \leq 0.01)$. Soils with high $\mathrm{SOM}$ and clay content usually have more binding sites for phosphate ions. No correlation was observed between $\mathrm{CaCO}_{3}$ content and ratios of different soil $\mathrm{P}$ pools, but a negative correlation was observed between the content and the ratio of inorganic $\mathrm{P} / \mathrm{TP}(\mathrm{P} \leq 0.01)$.

Significant correlations were observed between soil $P$ testing values using different methods $\left(R^{2} \geq 0.329\right.$, $\mathrm{P} \leq 0.01$, Table 3$)$. The differences in coefficients of determination were due to the different amounts of extractable $\mathrm{P}$ that were measured using different methods. The high correlation between inorganic $\mathrm{P}$ and $\mathrm{TP}\left(\mathrm{R}^{2}=0.957, \mathrm{P} \leq 0.01\right)$ indicated that inorganic forms of $\mathrm{P}$ dominated in the Loess Plateau area. Thus, it is important to explore the utilization of inorganic $\mathrm{P}$ in this area. There were high correlations between SOM and soluble $\mathrm{P}$, Olsen $\mathrm{P}_{\mathrm{dry}}$, DGT $\mathrm{P}_{\mathrm{dry}}$, inorganic $\mathrm{P}$, organic $P$, and TP $\left(R^{2} \geq 0.303, P \leq 0.01\right)$. It was reported that $P$ sorption capacity is determined by the SOM content in soils [42]. $\triangle$ Olsen $\mathrm{P}$ was positively correlated to soil $\mathrm{pH}$ $\left(\mathrm{R}^{2}=0.262, \mathrm{P} \leq 0.05\right)$ but negatively correlated to SOM $\left(\mathrm{R}^{2}=-0.380, \mathrm{P} \leq 0.01\right) . \Delta \mathrm{DGT} \mathrm{P}$ was highly correlated to $\mathrm{SOM}\left(\mathrm{R}^{2}=0.313, \mathrm{P} \leq 0.05\right)$, soluble $\mathrm{P}\left(\mathrm{R}^{2}=0.803\right.$, $\mathrm{P} \leq 0.01)$, Olsen $\mathrm{P}_{\text {dry }}\left(\mathrm{R}^{2}=0.652, \mathrm{P} \leq 0.01\right)$, DGT $\mathrm{P}_{\text {dry }}$ $\left(\mathrm{R}^{2}=0.776, \mathrm{P} \leq 0.01\right)$, inorganic $\mathrm{P}\left(\mathrm{R}^{2}=0.335, \mathrm{P} \leq 0.05\right)$, organic $P\left(R^{2}=0.452, P \leq 0.01\right)$, and $T P\left(R^{2}=0.417\right.$, $\mathrm{P} \leq 0.01)$. The DGT method measures $\mathrm{P}$ diffused from the soil solution and resupplied from the soil solid phase, which is associated with the $\mathrm{P}$ desorption rate. The $\mathrm{P}$ desorption rates and resupply from the soil solid phase were affected by the $\mathrm{P}$ status, as reflected by their high correlation with available $\mathrm{P}$ in soils, e.g., FeO strips, Olsen, and water-extractable P [43]. This explained the high correlation between $\triangle \mathrm{DGT} \mathrm{P}$ and soluble $\mathrm{P}$, Olsen $\mathrm{P}_{\mathrm{dry}}$, and DGT $\mathrm{P}_{\mathrm{dry}}$.

\section{Factors Affecting the Discrepancy of $\triangle \mathrm{DGT} P$}

As the $\triangle \mathrm{DGT} \mathrm{P}$ increased from group 1 to 3 , significant differences were observed among the 3 groups in organic $\mathrm{P}$ concentrations in soils (Fig. 3). Increases in $\mathrm{CEC}$ and $\mathrm{CaCO}_{3}$ as $\triangle \mathrm{DGT} \mathrm{P}$ increased were also observed, but the differences were not significant. A significant increase in organic $\mathrm{P}$ among the 3 groups of soils indicated that the concentration of organic $\mathrm{P}$ in soils was the main factor affecting the difference between using air-dried and moist soil samples to calculate DGT P. Molybdate reactive P in the acid eluent measured colorimetrically was used to calculate DGT
$\mathrm{P}$ values in a DGT test. However, the main P fractions extracted by the DGT method using the traditional acrylamide diffusive gel included inorganic $\mathrm{P}$ and parts of organic P from soil samples [43], where the organic $\mathrm{P}$ (accounting for a larger proportion than inorganic $\mathrm{P}$ ) cannot be included in the results. It was also reported that air-drying may increase the fragility of organic $\mathrm{P}$ in soils [44]. Therefore, we concluded that the larger discrepancy between DGT P values measured using airdried and moist soil samples was due to the conversion of easily mineralized organic P into inorganic P forms, which were then measured as part of inorganic P. Achat et al. [45] reported that the drying process (exposing samples to a temperature of $105^{\circ} \mathrm{C}$ ) reduced the total organic $\mathrm{P}$ and increased inorganic $\mathrm{P}$ in soils, especially in soils with high SOM. However, we did not observe a significant effect of SOM on $\triangle \mathrm{DGT} P$ values. This is probably due to the temperature during the air-drying process being much lower than that in Achat et al.'s research. We also did not find any differences in other parameters.

Although many results indicated that the DGT $\mathrm{P}$ results were highly related to plant uptake in most cases, some research suggested that DGT P was not the most accurate soil test for predicting plant $\mathrm{P}$ uptake [46]. The above results suggested that the discrepancy between DGT $P$ values obtained using air-dried and moist samples increased with an increase in the soil organic $\mathrm{P}$ concentration. This discrepancy might be the reason for the inaccuracy found by some researchers.

\section{Conclusions}

The study reported here has the unique feature of utilizing 58 different soils to investigate the effects of the air-drying process on soil $\mathrm{P}$ results obtained by traditional extraction and DGT methods. The difference in predicting soil available $\mathrm{P}$ using the Olsen $\mathrm{P}$ results obtained from air-dried and moist samples can be neglected due to their high correlational relationship, although significant difference was observed. However, a larger discrepancy between DGT $\mathrm{P}$ results was obtained from air-dried and moist samples. Specifically, the relative discrepancy between DGT P values increased as soil organic P increased. As the DGT method measures $\mathrm{P}$ in both inorganic and organic forms and the organic P measured by the DGT method was not stable, we concluded that a proportion of easily mineralized $\mathrm{P}$ was converted into its inorganic form during the air-drying process. Therefore, it is necessary to be cautious when measuring the plant available $\mathrm{P}$ in airdried soils using the DGT method, especially in soils with a high organic $\mathrm{P}$ content. In addition, care should be taken when using a DGT P test on soils with high CEC and $\mathrm{CaCO}_{3}$ contents. Further work needs to be carried out to identify these diffusive organic $\mathrm{P}$ compositions and their bioavailability to plants. 


\section{Acknowledgements}

This work was funded by the National Science Foundation of China (NSFC, project No. 41601324) and the Fundamental Research Funds for the Central Universities (No. 2452015283). We would also like to express great appreciation to the anonymous reviewers for thoughtful and professional comments and suggestions.

\section{Conflict of Interest}

The authors declare no conflict of interest.

\section{References}

1. ZHU W., ZHOU X., CHEN H., GAO L., XIAO M., LI M. High nutrient concentration and temperature alleviated formation of large colonies of Microcystis: evidence from field investigations and laboratory experiments. Water Research 101, 167, 2016.

2. NASH D.M., HALLIWELL D.J. Fertilizers and phosphorus loss from productive grazing systems. Soil Research 37 (3), 403, 1999.

3. OBERSTEINER M., PE UELAS J., CIAIS P., VAN DER VELDE M., JANSSENS I.A. The phosphorus trilemma. Nature Geoscience 6, 897. 2013.

4. MACDONALD G.K., BENNETT E.M., POTTER P.A., RAMANKUTTY N. Agronomic phosphorus imbalances across the world's croplands. Proceedings of the National Academy of Sciences 108 (7), 3086, 2011.

5. JORDAN-MEILLE L., RUB K., G.H., EHLERT P., GENOT V., HOFMAN G., GOULDING K., RECKNAGEL J., PROVOLO G., BARRACLOUGH P. An overview of fertilizer-P recommendations in Europe: soil testing, calibration and fertilizer recommendations. Soil Use and Management 28 (4), 419, 2012.

6. DAHLQVIST R., ZHANG H., INGRI J., DAVISON W. Performance of the diffusive gradients in thin films technique for measuring $\mathrm{Ca}$ and $\mathrm{Mg}$ in freshwater. Analytica Chimica Acta 460 (2), 247, 2002.

7. DAVISON W., ZHANG H. In situ speciation measurements of trace components in natural waters using thin-film gels. Nature 367, 546, 1994.

8. SCHINTU M., MARRAS B., DURANTE L., MELONI P., CONTU A. Macroalgae and DGT as indicators of available trace metals in marine coastal waters near a leadzinc smelter. Environmental Monitoring and Assessment 167 (1-4), 653, 2010.

9. ZHANG H., DAVISON W. Performance characteristics of diffusion gradients in thin films for the in situ measurement of trace metals in aqueous solution. Analytical Chemistry 67 (19), 3391, 1995.

10. ZHANG H., DAVISON W., MILLER S., TYCH W. In situ high resolution measurements of fluxes of $\mathrm{Ni}, \mathrm{Cu}, \mathrm{Fe}$, and $\mathrm{Mn}$ and concentrations of $\mathrm{Zn}$ and $\mathrm{Cd}$ in porewaters by DGT. Geochimica et Cosmochimica Acta 59 (20), 4181, 1995.

11. HUANG J., BENNETT W.W., TEASDALE P.R., GARDINER S., WELSH D.T. Development and evaluation of the diffusive gradients in thin films technique for measuring nitrate in freshwaters. Analytica Chimica Acta 923, 74, 2016

12. HUANG J.Y., BENNETT W.W., WELSH D.T., LI T.L., TEASDALE P.R. Development and evaluation of a diffusive gradients in a thin film technique for measuring ammonium in freshwaters. Analytica Chimica Acta 904, 83, 2016.

13. TANDY S., MUNDUS S., ZHANG H., LOMBI E., FRYDENVANG J., HOLM P.E., HUSTED S. A new method for determination of potassium in soils using diffusive gradients in thin films (DGT). Environmental Chemistry 9, 14, 2012.

14. ZHANG Y., MASON S., MCNEILL A., MCLAUGHLIN, M.J. Optimization of the diffusive gradients in thin films (DGT) method for simultaneous assay of potassium and plant-available phosphorus in soils. Talanta 113, 123, 2013.

15. ZHANG Y., NACHIMUTHU G., MASON S., MCLAUGHLIN M.J., MCNEILL A., BELL M.J. Comparison of soil analytical methods for estimating wheat potassium fertilizer requirements in response to contrasting plant $\mathrm{K}$ demand in the glasshouse. Scientific Reports 7 (1), 11391, 2017.

16. MASON S., MCLAUGHLIN M., JOHNSTON C., MCNEILL, A. Soil test measures of available P (Colwell, resin and DGT) compared with plant $\mathrm{P}$ uptake using isotope dilution. Plant and Soil 373, 711, 2013.

17. MASON S., MCNEILL A., MCLAUGHLIN M.J. Prediction of wheat response to an application of phosphorus under field conditions using diffusive gradients in thin-films (DGT) and extraction methods. Plant and Soil 337, 243, 2010.

18. SIX L., SMOLDERS E., MERCKX R. Testing phosphorus availability for maize with DGT in weathered soils amended with organic materials. Plant and Soil 376 (1-2), 177, 2014

19. SPEIRS S., SCOTT B., MOODY P., MASON S. Soil phosphorus tests II: A comparison of soil test-crop response relationships for different soil tests and wheat. Crop and Pasture Science 64 (5), 469, 2013.

20. ZHANG H., DAVISON W., GADI R., KOBAYASHI T. In situ measurement of dissolved phosphorus in natural waters using DGT. Analytica Chimica Acta 370 (1), 29, 1998.

21. VOGEL C., SEKINE R., STECKENMESSER D., LOMBI, E., STEFFENS D., ADAM C. Phosphorus availability of sewage sludge-based fertilizers determined by the diffusive gradients in thin films (DGT) technique. Journal of Plant Nutrition and Soil Science 180(5), 594, 2017.

22. MACKAY J.E., CAVAGNARO T.R., JAKOBSEN I., MACDONALD L.M., GRONLUND M., THOMSEN T.P., MULLER-STOVER D.S. Evaluation of phosphorus in thermally converted sewage sludge: $\mathrm{P}$ pools and availability to wheat. Plant and Soil 418 (1-2), 307, 2017.

23. MUNDUS S., CARSTENSEN A., HUSTED, S. Predicting phosphorus availability to spring barley (Hordeum vulgare) in agricultural soils of Scandinavia. Field Crops Research 212, 1, 2017.

24. MASON S., HAMON R., NOLAN A., ZHANG H., DAVISON, W. Performance of a mixed binding layer for measuring anions and cations in a single assay using the diffusive gradients in thin films technique. Analytical Chemistry 77 (19), 6339, 2005.

25. DEGRYSE F., SMOLDERS E., ZHANG H., DAVISON W. Predicting availability of mineral elements to plants with the DGT technique: a review of experimental data and 
interpretation by modelling. Environmental Chemistry $\mathbf{6}$ (3), 198, 2009.

26. DINH M.V., SCHRAMM T., SPOHN M., MATZNER E. Drying-rewetting cycles release phosphorus from forest soils. Journal of Plant Nutrition and Soil Science 179 (5), 670, 2016

27. B NEMANN E.K., KELLER B., HOOP D., JUD K., BOIVIN P., FROSSARD E. Increased availability of phosphorus after drying and rewetting of a grassland soil: processes and plant use. Plant and Soil 370 (1-2), 511, 2013.

28. ERICH M.S., HOSKINS B.R. Effects of soil drying on soil $\mathrm{pH}$ and nutrient extractability. Communications in Soil Science and Plant Analysis 42 (10), 1167, 2011.

29. RAYMENT G.E., LYONS D.J. Soil Chemical MethodsAustralia. Melbourne, CSIRO Publishing. 2010.

30. RAYMENT G.E., HIGGINSON F.R. Australian laboratory handbook of soil and water chemical methods. Melbourne, Inkata Press. 1992.

31. NELSON D.V., SOMMERS L.E. Total carbon, organic carbon, and organic matter. Methods of Soil Analysis. Part 3: Chemical Methods. D. L. Sparks. Madison, WI, Soil Science Society of America: 539, 1996.

32. BENTON J., JONES J. Laboratory Guide for Conducting Soil Tests and Plant Analysis. Washington, D.C., CRC Press. 2001.

33. KUO S. Phosphorus. Methods of Soil Analysis. Part 3: Chemical Methods. D. L. Sparks. Madison, WI, Soil Science Society of America: 869, 1996.

34. OLSEN S.R. Estimation of available phosphorus in soils by extraction with sodium bicarbonate, United States Department of Agriculture; Washington. 1954.

35. JIANG B., GU Y. A suggested fractionation scheme of inorganic phosphorus in calcareous soils. Fertilizer Research 20 (3), 159, 1989.

36. MASON S., HAMON R., ZHANG H., ANDERSON J. Investigating chemical constraints to the measurement of phosphorus in soils using diffusive gradients in thin films (DGT) and resin methods. Talanta 74 (4), 779, 2008.

37. OBALUM S.E., CHIBUIKE G.U. Air-drying effect on soil reaction and phosphorus extractability from uplandlowland tropical soils as related to their colloidal stability. Applied Ecology and Environmental Research 15 (1), 525, 2017.
38. OBALUM S.E., NWITE J.C., WATANABE Y., IGWE C.A., WAKATSUKI T. Comparative topsoil characterization of Sawah rice fields in selected inland valleys around Bida, North-Central Nigeria. Tropical Agriculture and Development 56 (2), 39, 2012.

39. RABEHARISOA L., RAZANAKOTO O.R., RAZAFIMANANTSOA M.P., RAKOTOSON T., AMERY F., SMOLDERS E. Larger bioavailability of soil phosphorus for irrigated rice compared with rainfed rice in Madagascar: results from a soil and plant survey. Soil Use and Management 28 (4), 448, 2012.

40. SOINNE H., RATY M., HARTIKAINEN H. Effect of air-drying on phosphorus fractions in clay soil. Journal of Plant Nutrition and Soil Science 173 (3), 332, 2010.

41. ACHAT D.L., POUSSE N., NICOLAS M., BR DOIRE F., AUGUST, L. Soil properties controlling inorganic phosphorus availability: general results from a national forest network and a global compilation of the literature. Biogeochemistry 127 (2-3), 255, 2016.

42. DEBICKA M., KOCOWICZ A., WEBER J., JAMROZ E. Organic matter effects on phosphorus sorption in sandy soils. Archives of Agronomy and Soil Science 62 (6), 840, 2016.

43. MENEZES-BLACKBURN D., ZHANG H., STUTTER M., GILES C.D., DARCH T., GEORGE T.S., SHAND C., LUMSDON D., BLACKWELL M., WEARING C., COOPER P., WENDLER R., BROWN L., HAYGARTH P.M. A holistic approach to understanding the desorption of phosphorus in soils. Environmental Science \& Technology 50 (7), 3371, 2016.

44. ETCHEVERS J. Chemical soil analyses- the reason for their drawbacks. Proceedings of an International Workshop on the Laboratory Methods and Data Exchange Programme'. (Ed. LK Pleijsier) pp 16-34, The Netherlands, Labex Secretariat. 1986.

45. ACHAT D.L., AUGUSTO L., GALLET-BUDYNEK A., BAKKER M.R. Drying-induced changes in phosphorus status of soils with contrasting soil organic matter contents - Implications for laboratory approaches. Geoderma 187, 41, 2012

46. SIX L., SMOLDERS E., MERCKX R. The performance of DGT versus conventional soil phosphorus tests in tropical soils- maize and rice responses to P application. Plant and Soil 366 (1-2), 49, 2013. 
